\title{
Spatial and temporal variability of patterns of colonization by mussels (Mytilus trossulus, M. edulis) on a wave-exposed rocky shore
}

\author{
Heather L. Hunt ${ }^{*}$, Robert E. Scheibling \\ Department of Biology, Dalhousie University, Halifax, Nova Scotia B3H 4J1, Canada
}

\begin{abstract}
Colonization rates of mussels (Mytilus trossulus and $M$. edulis) were measured on natural substrata in tidepools and on emergent rock in recently ice-scoured and non-scoured regions of a rocky shore near Halifax, Nova Scotia, Canada. The relative importance of initial settlement/colonization. compared to subsequent dispersal and mortality, in determining the distribution and abundance of mussels was examined by comparing patterns and rates of mussel colonization at sampling intervals of days to months over a 17 mo period. Less than $4 \%$ of mussels which colonized the quadrats sampled at short ( 2 to $7 \mathrm{~d}$ ) intervals were settling larvae $(<0.5 \mathrm{~mm}$ shell length), indicating the importance of postsettlement dispersal of mussels on this shore. Most colonists were $>2 \mathrm{~mm}$, too large to be dispersed by byssal drifting, suggesting they were redistributed by wave dislodgment and deposition. At both short ( 2 to $7 \mathrm{~d}$ ) and long (5 to $16 \mathrm{mo}$ ) sampling intervals, colonists were most abundant in ice-scoured tidepools and least abundant on ice-scoured emergent rock, probably reflecting differences in the macrobenthic assemblage the subatratum for colonization. In addition, the long len disundance of colonists was linearly related to the cumulative short term abundance during all but one of the intervals. Therefore, our results indicate that, over time scales up to $16 \mathrm{mo}$, patterns of initial colonization by settlers and larger post-larval mussels were more important than post-colonization mortality and dispersal in determining patterns of distribution and abundance of mussels on this shore.
\end{abstract}

KEY WORDS: Colonization Post-settlement dispersal - Mussels $\cdot$ Mytilus Ice scour Intertidal zone Tidepools

\section{INTRODUCTION}

Studies of the role of recruitment variability in the population and community dynamics of benthic marine invertebrates have focused largely on processes influencing patterns of settlement by plank tonic larvae (reviewed by Butman 1987, Pawlik 1992, Rodriguez et al. 1993). However, many benthic marine invertebrates, particularly molluscs, can disperse in the water column as juveniles (e.g. Sigurdsson et al. 1976, Beukema \& de Vlas 1989, Martel \& Chia 1991b, Armonies 1992). When the rate of waterborne dispersal of juveniles is high, it may be an important determinant of the distribution and abundance of adults

\footnotetext{
- Present address: MS 34, Woods Hole Oceanographic Institution, Woods Hole, Massachusetts 02543, USA.

E-mail: hlhunt@whoi.edu
}

(Woodin 1991). Post-settlement transport of juvenile molluscs can be actively initiated (Martel \& Chia 1991a), and is generally facilitated by the production of long byssal or mucous threads which increase hydrodynamic drag (Sigurdsson et al. 1976, De Blok \& TanMaas 1977, Lane et al. 1985, Martel \& Chia 1991a). Young post-larval mussels can use threads to drift in the water column at least until they reach a size of $\sim 2 \mathrm{~mm}$ shell length (Sigurdsson et al. 1976, De Blok \& Tan-Maas 1977, Lane et al. 1985). Bayne (1964) demonstrated that Mytilus edulis entered a secondary pelagic phase at a size of 1 to $2 \mathrm{~mm}$ and moved from initial settlement sites on filamentous algae to a more permanent attachment on established beds of adult mussels. Although a temporary association between recently settled mussels and filamentous algae has been observed in several other studies (e.g. Seed 1969, King et al. 1989), mussels also may settle directly onto 
adult mussel beds (McGrath et al. 1988, CáceresMartínez et al. 1993, 1994). Patterns of post-settlement dispersal may partially account for sporadic and unpredictable pulses of recruitment which characterize many populations of Mytilus (Seed \& Suchanek 1992). Although byssal drifting in the water column generally involves small juveniles, larger mussels may be redistributed by wave action or may move by crawling (Paine 1974, Hunt 1997). Dispersal of large mussels may increase the rate of recovery of mussel cover after disturbance and influence the dynamics of established mussel aggregations.

In this study, we examine patterns and rates of colonization of mussels (Mytilus trossulus, $M$. edulis) in tidepools and on emergent rock, both in ice-scoured and non-scoured regions of an exposed shore in Nova Scotia, Canada. The abundance and spatial distribution of mussels differ between tidepools and emergent rock: mussels in tidepools generally occur in centimeter-scale patches, whereas those on emergent rock tend to form more extensive beds with centimeterscale gaps (Hunt \& Scheibling 1995, Minchinton et al. 1997). Tidepools and emergent rock differ in several aspects which may influence mussel colonization (see also Hunt \& Scheibling 1996). For example, they have different macroalgal assemblages (the substrata upon which mussels settle) and they are differentially affected by occasional ice scour which generally disturbs tidepools less than emergent rock. To examine the relative importance of initial settlement/colonization compared to subsequent dispersal and mortality in determining the distribution and abundance of mussels, we compare patterns and rates of mussel colonization at sampling intervals of days to months over a 17 mo period

\section{MATERIALS AND METHODS}

This study was conducted at an exposed rocky shore at Cranberry Cove $\left(44^{\circ} 28^{\prime} \mathrm{N}, 63^{\circ} 56^{\prime} \mathrm{W}\right)$ near Halifax, Nova Scotia, Canada. The shore is composed of granite platforms and outcrops with occasional large boulders (glacial erratics). There are numerous tidepools in irregular depressions along the shore, ranging from a few decimeters to over $10 \mathrm{~m}$ in maximum dimension. The shore is exposed to southerly swells which may reach $10 \mathrm{~m}$ in significant wave height (average height of the largest $1 / 3$ of all waves measured) in fall and winter (Hunt 1997). For a further description of the study site, see Metaxas et al. (1994) and Hunt \& Scheibling (1995, 1996).

Because Mytilus trossulus and $M$. edulis, the 2 species of mussels at our study site, cannot be distinguished visually at small size, we used a genetic assay to compare the relative abundance of the 2 species between habitats. In March 1997, we collected 32 mussels in 3 size classes from each of 3 tidepools and 3 adjacent areas of emergent rock, $<5 \mathrm{~mm}(\mathrm{n}=8)$, 5-9.9 mm ( $\mathrm{n}=8$ ), and 10-24.9 $\mathrm{mm}$ shell length (SL) ( $n=16$ ). The mussels were identified to species using a polymerase chain reaction assay of a marker for internal transcribed spacer regions between the $18 \mathrm{~S}$ and 28S nuclear rDNA coding regions (Heath et al. 1995). DNA was extracted from the whole animal for mussels $<10 \mathrm{~mm}$, and from gill tissue for individuals $\geq 10 \mathrm{~mm}$.

Between July 1993 and December 1994, we measured colonization by mussels in 2 habitats, tidepools and emergent rock, within each of 2 strata in the mid intertidal zone, areas scoured by sea ice in the winter of 1992-1993 and non-scoured areas. This ice scour occurred at scales of metres to tens of metres along several kilometres of shoreline. Ice scour did not occur again during our study. Ice-scoured areas were identified in the spring of 1993 from changes in the macrobenthic assemblage. On emergent rock, ice scour removed all upright macroalgae including the canopy of fucoid algae, resulting in the death of the underlying crustose algae. Ice scour affected the macrobenthic community in tidepools less severely and some upright macroalgae remained. To set up a factorial design, we selected 12 plots (tidepools or areas of emergent rock) along a horizontal distance of $\sim 1 \mathrm{~km}$ of shoreline to make up 3 replicates of each of the 4 combinations of habitat and stratum. Tidepools ranged from 2.7 to $7.2 \mathrm{~m}$ in length, 1.1 to $2.8 \mathrm{~m}$ in width, and 0.3 to $0.6 \mathrm{~m}$ in depth; plots of emergent rock were comparable in area. The physical characteristics of ice-scoured and non-scoured plots differed because ice scour had occurred primarily in the most wave-exposed locations. An index of water flux, the dissolution rate of cylinders of dental stone, was higher in ice-scoured than non-scoured areas, and higher on emergent rock than in tidepools (Hunt \& Scheibling 1996). Non scoured tidepools were somewhat higher on the shore (1.4 to $2.3 \mathrm{~m}$ above chart datum) than the other combinations of habitat and stratum (0.8 to $1.6 \mathrm{~m}$ ) (Hunt \& Scheibling 1996).

We recorded colonization by mussels within $10 x$ $10 \mathrm{~cm}$ quadrats on the natural substratum. We prepared 12 quadrats per plot in July 1993 by removing the existing mussels with forceps or a pipette to avoid disturbing the rest of the macrobenthic community. We also removed mussels (with a paint scraper) from a $10 \mathrm{~cm}$ border around each quadrat to limit migration into the quadrat. The quadrats were spaced at least $10 \mathrm{~cm}$ apart and marked by stainless steel screws in plastic anchors. We define initial colonization as the arrival of mussels in the quadrats by larval settlement and/or post-settlement dispersal (secondary settlement, sensu Bayne 
1964). We examined the effects of post-colonization mortality and dispersal on patterns of initial colonization of mussels by sampling quadrats (i.e. collecting all mussel colonists) at different frequencies, since the extent of mortality and dispersal will be directly related to the interval between samples (Minchinton \& Scheibling $1993 b$ ). We sampled 3 quadrats per plot at short sampling intervals, from $2-7 \mathrm{~d}$ (spring to fall) to $30 \mathrm{~d}$ (winter), resulting in a total of 105 sampling dates over 17 mo. We examined patterns of longer term colonization over the same period by sampling mussels in 3 quadrats per plot at each of 3 successive 5 to 6 mo intervals, i.e. in November 1993 (5 mo), May 1994 (11 mo), and October 1994 (16 mo). To examine the effects of season on patterns of long term colonization, we collected colonists from the initial 5 mo quadrats at 2 other times, May and November 1994, after 5 to 6 mo periods. This enabled us to examine seasonal variation between a winter interval, November 1993 to May 1994, and the preceding and subsequent summer/fall intervals (July to November 1993, May to October 1994). Therefore, of the 12 quadrats prepared per plot, 3 were sampled repeatedly at short sampling intervals ( 2 to $7 \mathrm{~d}$ ), 3 were sampled at the end of each of three 5 to 6 mo intervals, 3 were sampled once after $11 \mathrm{mo}$, and 3 were sampled once after 16 mo.

Mussels were collected from each quadrat using forceps or a pipette. A magnifying glass was used to detect settlers and small post-larval mussels. A small proportion of $<0.5 \mathrm{~mm}$ mussels, particularly those in filamentous or jointed calcareous algae, may not have been detected. Unless these individuals died or dispersed immediately, they would have been detected when they grew larger. In ice-scoured tidepools where they were most abundant (see Fig. 1), <0.5 mm mussels occurred primarily in pits and crevices in rock covered by crustose algae (Phymatolithon sp.) and at the base of Chondrus crispus holdfasts, substrata on which they were quite visible. After the short sampling intervals ( 2 to $7 \mathrm{~d}$ ) and the first and second 5 to 6 mo intervals, mussels were collected without disturbing the rest of the macrobenthic assemblage. After the $11 \mathrm{mo}$, the $16 \mathrm{mo}$, and the third 5 to 6 mo interval, mussels were collected by removing all macroalgae from the quadrats since these quadrats would not be sampled again. Removal of all of the macroalgae during sampling reduced the time required in the field, but may have slightly increased the number of $<0.5 \mathrm{~mm}$ mussels detected. However, it should not have introduced a large bias in the counts. Samples were frozen until they could be processed. Mussels were counted and shell length was measured in 0.5 or $1 \mathrm{~mm}$ size classes using an ocular micrometer on a dissecting microscope for the smallest individuals, or vernier calipers for larger ones (>5 mm SL).
We grouped the mussels collected at the shortest sampling intervals ( 2 to $7 \mathrm{~d}$ ) into 4 size classes: $<0.5$, $0.5-1.9,2-4.9$, and $>5 \mathrm{~mm}$ SL. We refer to mussels which are $<0.5 \mathrm{~mm}$ SL as settlers because they are equal to or smaller than the maximum size of settling larvae (Bayne 1965). We grouped 0.5 to $1.9 \mathrm{~mm}$ mussels because individuals in this size class are capable of drifting using threads and are known to disperse frequently in some populations (reviewed by Seed \& Suchanek 1992). We summed, separately, the total number of mussels from each size class collected from each quadrat for each of the 2 main colonization periods in our study: July to November 1993 and May to November 1994. Short term colonization rate was negligible during winter/early spring (see 'Results'). Analyses were carried out using ANOVA. Cumulative colonization based on short term samples was compared among plots, habitats (tidepool, emergent rock), and strata (scoured, non-scoured) for each size class in both the 1993 and 1994 colonization periods. In the analysis, Habitat and Stratum are fixed factors, each with 2 levels, and Plot is a random factor nested within Habitat $\times$ Stratum, with 3 levels. Effects of Habitat, Stratum, and the interaction between Habitat and Stratum were tested against the mean square error of Plot, and the effect of Plot was tested against the residual mean square error. The numbers of colonists at the end of the three 5 to $6 \mathrm{mo}$ intervals were analyzed using the same model. To compare colonization at the end of the 5,11, and 16 mo intervals beginning in 1993, Time, a fixed factor with 3 levels $(5,11,16 \mathrm{mo})$, was added to the model. Effects of Time and the interactions between Time, Habitat, and Stratum were tested against the mean square error of the interaction between Time and Plot. The interaction between Time and Plot was tested against the residual mean square error. Prior to ANOVA, the raw data were $\log$ or $\log (x+1)$ transformed to successfully remove heterogeneity of variance, as detected by Cochran's test $(\alpha=0.05)$. For post-hoc comparisons of means $(\alpha=0.05)$, we used $t$-tests for comparisons of 2 means and StudentNewman-Keuls (SNK) tests for comparisons of multiple means

We measured the cover of macroalgae, barnacles (Semibalanus balanoides), and mussels on the substratum in each of the quadrats in September 1993 and April, July, and October 1994. A plexiglass panel with 20 random points was placed over a quadrat and the number of points overlying each species was counted and expressed as a percentage of the total. Macroalgae were assigned to functional form groups after Littler (1980) and Littler \& Littler (1984): sheets, filamentous, coarsely branched, thick leathery, jointed calcareous and crustose forms. 


\section{RESULTS}

\section{Species composition}

We compared the frequency of Mytilus trossulus and $M$. edulis (Table 1) among size classes $(<5,5-9.9$, $\geq 10 \mathrm{~mm}$ ) and between tidepools and emergent rock using contingency tables. Hybrids were not included in the analysis because of their low abundance $(\leq 3$ individuals per size class per habitat). The frequency of occurrence of $M$. trossulus and $M$. edulis did not differ significantly among size classes in tidepools $\left(G_{2}=1.93\right.$, $\mathrm{p}=0.38)$ or on emergent rock $\left(G_{2}=5.64, \mathrm{p}=0.06\right)$, although the difference on emergent rock was only marginally non-significant. The frequency of $M$. trossulus (pooled across size classes) did not differ signifi- cantly between tidepools $(76 \%)$ and emergent rock $(66 \%)\left(G_{1}=1.20, \mathrm{p}=0.27\right)$. These results are consistent with a similar analysis of mussels collected the previous year which indicated that $\sim 80 \%$ of mussels in both habitats were M. trossulus (Hunt \& Scheibling 1996). At another wave-exposed shore in Nova Scotia (ca $30 \mathrm{~km}$ away), Pedersen (1991) found that 77 to $91 \%$ of settlers ( $<1 \mathrm{~mm} \mathrm{SL})$ and 76 to $90 \%$ of older individuals (from $6 \mathrm{mo}, 10 \mathrm{mo}$, and $24 \mathrm{mo}$ old mussel patches) on emergent rock were $M$. trossulus.

\section{Colonization over short sampling intervals}

Less than $4 \%$ of mussels which colonized the quadrats sampled at short ( 2 to 7 d) intervals (Fig. 1)

Table 1 Frequency of Mytilus trossulus, M. edulis, and hybrids of the 2 species in 3 size classes $(<5,5-9.9$, and $10-24.9 \mathrm{~mm})$ of mussels collected from tidepools and emergent rock

\begin{tabular}{|llccc}
\hline Size class & Habitat & M. trossulus & M. edulis & Hybrids \\
\hline$<5 \mathrm{~mm}$ & Tidepool & 13 & 6 & 1 \\
$5-9.9 \mathrm{~mm}$ & Emergent rock & 20 & 3 & 0 \\
\multirow{3}{*}{$10-24.9 \mathrm{~mm}$} & Tidepool & 19 & 3 & 9 \\
& Emergent rock & 11 & 10 & 3 \\
Total & Tidepool & 36 & 13 & 3 \\
& Emergent rock & 30 & $19(21 \%)$ & $3(3 \%)$ \\
\end{tabular}
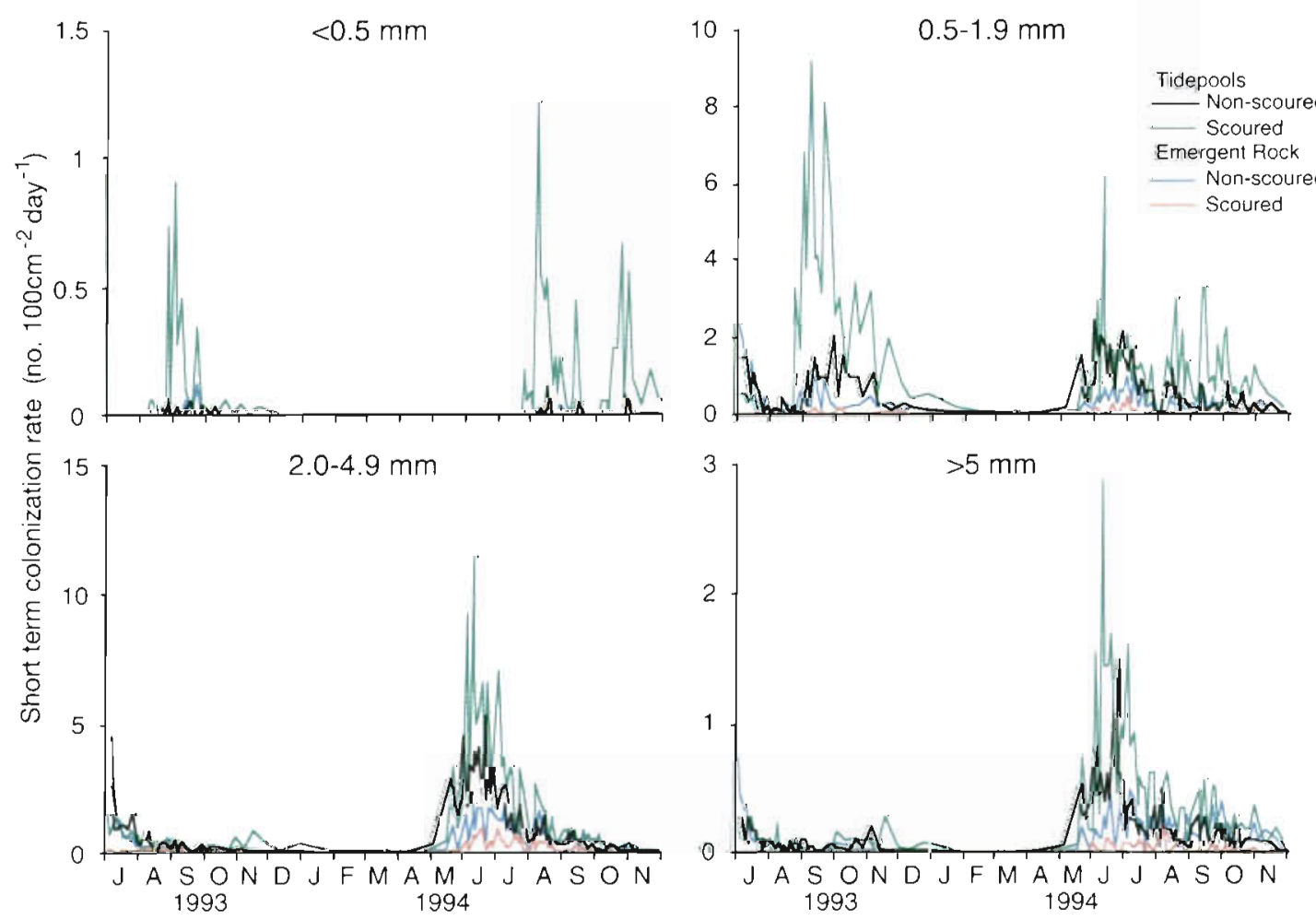

Fig. 1 Mytilus spp Colonization rate of mussels of each of 4 size classes $1<0.5$, $0.5-1.9,2-4.9$, and $>5 \mathrm{~mm}$ SL) in quadrats in icescoured and nonscoured tidepools and emergent rock monitored at short (2 to 7 d.) sampling intervals from July 1993 to November 1994. Data were averaged across 3 quadrats per plot and across 3 plots within each combination of habitat and stratum 
Table 2. Mytilus spp. Three-factor ANOVA of the cumulative density (no. $100 \mathrm{~cm}^{-2}$ ) of mussels of each of 4 size classes colonizing quadrats sampled at short intervals from July to November 1993 and from May to November 1994. Factors are Habitat (H, tidepools and emergent rock), Stratum ( $\mathrm{S}$, ice-scoured and non-scoured), and Plot (nested within $\mathrm{H} \times \mathrm{S}$ ). Effects of Habitat, Stratum, and the interaction between Habitat and Stratum were tested against the mean square error of Plot, and the effect of Plot was tested against the residual mean square error. ${ }^{\circ} p<0.05 ;{ }^{\prime} p<0.01 ; \cdots p<0.001$. The results of a posteriori tests are presented in the 'Comparison' column. When there was a significant $\mathrm{H} \times \mathrm{S}$ interaction, means were compared between habitats within each stratum and between strata within each habitat using t-tests (TP = tidepool, ER = emergent rock, $\mathrm{N}-\mathrm{S}=$ non-scoured, $\mathrm{S}=\mathrm{ice}$ scoured). $=$ indicates a non-significant result, while $<$ or $>$ indicates a significant result $(\alpha=0.05)$

\begin{tabular}{|c|c|c|c|c|c|c|}
\hline Size class & Source & df & MS & $F$ & $\mathrm{p}$ & Comparison \\
\hline \multicolumn{7}{|l|}{1993} \\
\hline \multirow[t]{5}{*}{$<0.5 \mathrm{~mm}$} & Habitat & 1 & 2.01 & 27.72 & $<0.001 \cdots$ & $T P: N-S<S$ \\
\hline & Stratum & 1 & 0.81 & 11.14 & $0.01^{\bullet}$ & $E R: N-S=S$ \\
\hline & Habitat $\times$ Stratum & 1 & 1.34 & 18.50 & $0.003^{\cdots}$ & $N-S: T P=E R$ \\
\hline & Plot $(\mathrm{H} \times \mathrm{S})$ & 8 & 0.07 & 1.48 & 0.22 & $S: T P>E R$ \\
\hline & Residual & 24 & 0.05 & & & \\
\hline \multirow[t]{5}{*}{$0.5-1.9 \mathrm{~mm}$} & Habitat & 1 & 11.46 & 17.64 & $0.003 \cdots$ & TP: N-S=S \\
\hline & Stratum & 1 & 0.25 & 0.38 & 0.55 & ER: $N-S>S$ \\
\hline & Habitat $\times$ Stratum & 1 & 6.57 & 10.11 & $0.01^{\circ}$ & $N-S: T P=E R$ \\
\hline & Plot $(\mathrm{H} \times \mathrm{S})$ & 8 & 0.65 & 3.71 & $0.006^{\cdots}$ & $S: T P>E R$ \\
\hline & Residual & 24 & 0.18 & & & \\
\hline \multirow[t]{5}{*}{$2-4.9 \mathrm{~mm}$} & Habitat & 1 & 4.58 & 15.79 & $0.004^{\cdots}$ & $T P: N-S=S$ \\
\hline & Stratum & 1 & 2.39 & 8.23 & $0.02^{\circ}$ & $E R: N-S>S$ \\
\hline & Habitat $\times$ Stratum & 1 & 2.44 & 8.41 & $0.02^{\bullet}$ & $N-S: T P=E R$ \\
\hline & $\operatorname{Plot}(\mathrm{H} \times \mathrm{S}\}$ & 8 & 0.29 & 2.21 & 0.07 & $S: T P>E R$ \\
\hline & Residual & 24 & 0.14 & & & \\
\hline \multirow[t]{5}{*}{$>5 \mathrm{~mm}$} & Habitat & 1 & 2.45 & 34.39 & $<0.001^{\cdots}$ & TP: $N-S=S$ \\
\hline & Stratum & 1 & 0.88 & 12.30 & $0.008 \cdots$ & ER: N-S>S \\
\hline & Habitat $\times$ Stratum & 1 & 1.18 & 16.54 & $0.004^{\cdots}$ & $N-S: T P=E R$ \\
\hline & Plot $(H \times S)$ & 8 & 0.07 & 0.89 & 0.54 & $S: T P>E R$ \\
\hline & Residual & 24 & 0.08 & & & \\
\hline \multicolumn{7}{|l|}{1994} \\
\hline \multirow[t]{5}{*}{$<0.5 \mathrm{~mm}$} & Habitat & 1 & 3.82 & 21.56 & $0.002^{\cdots}$ & TP: $N-S<S$ \\
\hline & Stratum & 1 & 2.06 & 11.64 & $0.009 \cdots$ & $E R: N-S=S$ \\
\hline & Habitat $\times$ Stratum & 1 & 1.79 & 10.07 & $0.01^{\circ}$ & N-S: TP=ER \\
\hline & Plot $(\mathrm{H} \times \mathrm{S})$ & 8 & 0.18 & 4.40 & $0.002 \cdots$ & $S: T P>E R$ \\
\hline & Residual & 24 & 0.04 & & & \\
\hline \multirow[t]{5}{*}{$0.5-1.9 \mathrm{~mm}$} & Habitat & 1 & 6.26 & 15.75 & $0.004^{\cdots}$ & TP: N-S=S \\
\hline & Stratum & 1 & 0.53 & 1.33 & 0.28 & ER: N-S>S \\
\hline & Habitat $\times$ Stratum & 1 & 2.71 & 6.81 & $0.03^{\circ}$ & $N-S: T P=E R$ \\
\hline & Plot $(H \times S)$ & 8 & 0.40 & 3.90 & $0.005^{\cdots}$ & $S: T P>E R$ \\
\hline & Residual & 24 & 0.10 & & & \\
\hline \multirow[t]{5}{*}{$2-4.9 \mathrm{~mm}$} & Habitat & 1 & 3.70 & 15.50 & $0.004 \cdots$ & \\
\hline & Stratum & 1 & 0.06 & 0.26 & 0.62 & \\
\hline & Habitat $\times$ Stratum & 1 & 1.18 & 4.96 & 0.06 & \\
\hline & Plot $(\mathrm{H} \times \mathrm{S})$ & 8 & 0.24 & 2.32 & 0.05 & \\
\hline & Residual & 24 & 0.10 & & & \\
\hline \multirow[t]{5}{*}{$>5 \mathrm{~mm}$} & Habitat & 1 & 4.60 & 28.81 & $<0.001 \cdots$ & $T P: N-S=S$ \\
\hline & Stratum & 1 & 0.12 & 0.78 & 0.40 & ER: N-S>S \\
\hline & Habitat $\times$ Stratum & 1 & 2.08 & 13.05 & $0.01^{\circ}$ & N-S: TP=ER \\
\hline & Plot $(\mathrm{H} \times \mathrm{S})$ & 8 & 0.16 & 1.45 & 0.23 & $S: T P>E R$ \\
\hline & Residual & 24 & 0.110 & & & \\
\hline
\end{tabular}

were settling larvae $(<0.5 \mathrm{~mm} \mathrm{SL})$. Settlement occurred from August to November, while larger mussels colonized the quadrats over a more extended period from May to December. The daily colonization rate by all size classes of mussels was negligible in winter/ early spring (January to April 1994). Settlement of $<0.5 \mathrm{~mm}$ mussels peaked in September in 1993 and in
August and October/November in 1994. Colonization by larger size classes was at a peak when sampling began in July 1993 and peaked again in June/July 1994. Colonization by $0.5-1.9 \mathrm{~mm}$ mussels also peaked in September/October in both years.

ANOVA (Table 2) showed a significant interaction in the effects of Habitat and Stratum on the cumulative 


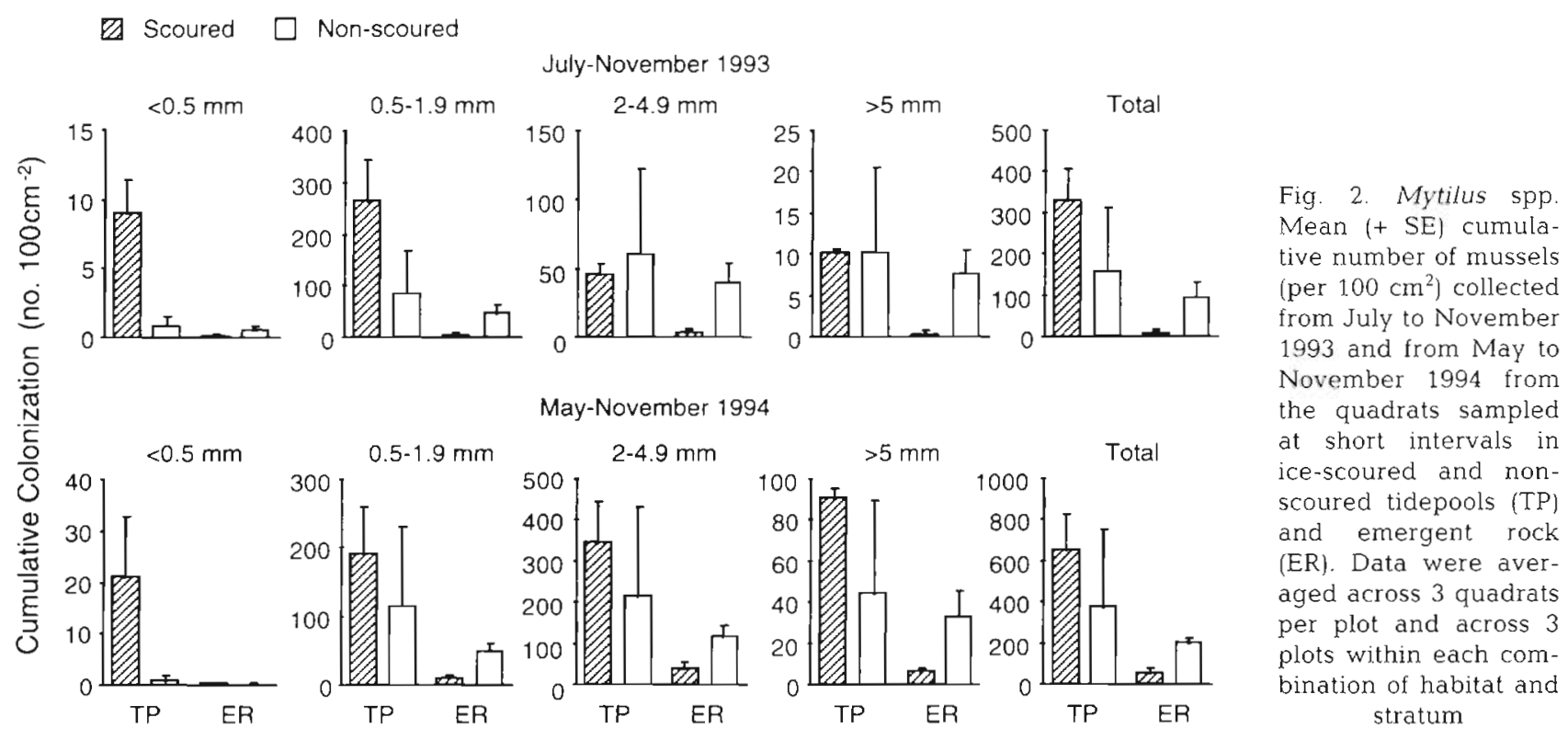

density of colonists for each size class of mussels in both years, except for 2-4.9 mm mussels in 1994 when the interaction was marginally non-significant and the cumulative density of colonists was significantly higher in tidepools than on emergent rock. Post hoc comparisons of means showed that settlers $(<0.5 \mathrm{~mm})$ were 1 to 2 orders of magnitude more abundant in tidepools than on emergent rock in ice-scoured areas, but did not differ significantly between habitats in nonscoured areas (Fig. 2, Table 2). Cumulative abundance of settlers was significantly higher in ice-scoured than in non-scoured areas in tidepools, but did not differ significantly between strata on emergent rock. In contrast, cumulative abundance of larger colonists was more similar among ice-scoured tidepools, and nonscoured tidepools and emergent rock, but was consistently lowest on ice-scoured emergent rock (Fig. 2). Cumulative colonization by these larger mussels was significantly higher in tidepools than on emergent rock in ice-scoured areas, but did not differ significantly between habitats in non-scoured areas (Table 2). Moreover, colonization by larger mussels was significantly higher in non-scoured than in ice-scoured areas on emergent rock, but did not differ between strata in tidepools. There was significant variation among plots for initial settlers in 1994 but not in 1993, and for 0.5-1.9 mm mussels in both years. Variation among plots in the cumulative colonization by $2-4.9 \mathrm{~mm}$ mussels was marginally non-significant in both years, but there was clearly no significant effect of Plot for $>5 \mathrm{~mm}$ mussels. In both 1993 and 1994, the cumulative number of colonists summed across size classes was highest in ice-scoured tidepools and lowest on ice-scoured emergent rock (Fig. 2). We did not compare colonization between years because sampling in 1993 began in July when colonization by large mussels was at a peak.

We examined the size distributions of mussel colonists by pooling individuals over the main colonization periods in 1993 and 1994 (Fig. 3). Small mussels were proportionately more abundant in 1993, when sampling began in July, than in 1994, when sampling was carried out throughout the entire colonization period. In each year, $\leq 3 \%$ of colonists in any habitat/stratum combination were recent settlers $(<0.5 \mathrm{~mm})$. Mussels that were $0.5-1.9 \mathrm{~mm}$ represented the majority ( 50 to $81 \%$ ) of colonists in 1993, while $2-4.9 \mathrm{~mm}$ mussels were the most abundant (53 to $71 \%$ ) colonists in 1994 . Mussels that were $>5 \mathrm{~mm}$ represented 3 to $8 \%$ of colonists in 1993 and 11 to $16 \%$ in 1994. For each year, we compared the size distributions of mussels between strata within each habitat and between habitats within each strata using Kolmogorov-Smirnov tests (Seigel \& Castellan 1988) (Fig. 3). Mussels were pooled across quadrats and plots within a habitat/stratum combination. In both years, mussels $<1 \mathrm{~mm}$ were proportionately more abundant in ice-scoured tidepools than in the other combinations of habitat and stratum, such that the size distributions of colonists differed significantly between ice-scoured and non-scoured tidepools, and between ice-scoured tidepools and ice-scoured emergent rock. On emergent rock, size distributions of colonists did not differ significantly between non-scoured and ice-scoured areas in each year In non-scoured areas, size distributions of colonists did not differ significantly between tidepools and emergent rock in 1993. However, this 
difference was statistically significant in 1994, which reflected larger sample sizes in 1994 since the degree of difference remained small $\left(D_{\max }=0.07\right)$.

\section{Colonization over long sampling intervals}

The pattern of long term colonization was similar to the pattern of cumulative short term colonization (summed over all size classes of mussels): abundance was highest in ice-scoured tidepools and lowest on ice-scoured emergent rock (Fig, 4). For the 5, 11, and 16 mo intervals beginning in July 1993, ANOVA showed a significant interaction in the effects of Habitat and Stratum on the density of mussel colonists (Table 3). Post hoc comparison of means showed that the patterns of differences between habitats within strata, and between strata within habitats, were the same as those of cumulative short term colonization of mussels $>0.5 \mathrm{~mm}$, i.e. colonization was greater in tidepools than on emergent rock in ice-scoured areas, and greater on non-scoured than on icescoured emergent rock. Colonization increased significantly over time, but not in proportion to the time elapsed: abundance after 5 and 11 mo was 70 and

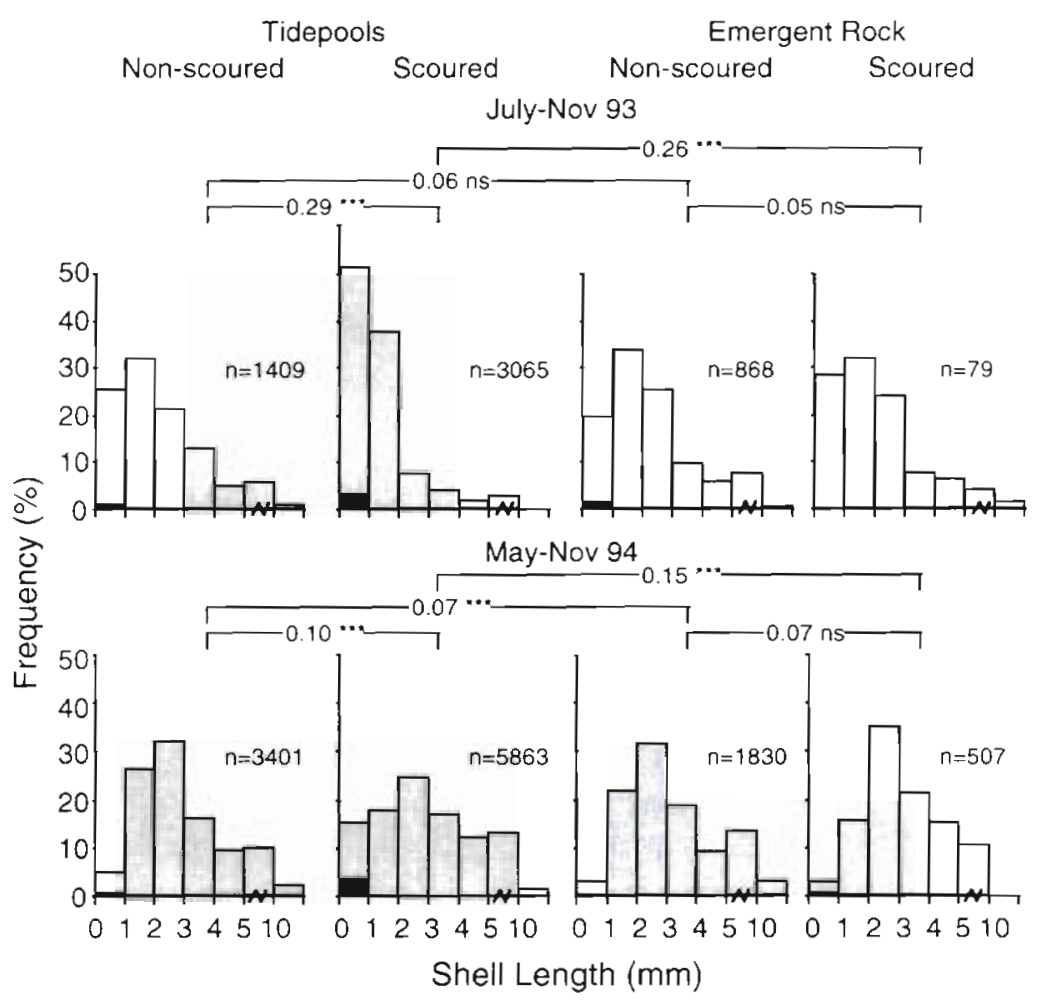

Fig. 3. Mytilus spp. Size frequency distributions of mussels collected from July to November 1993 and from May to November 1994 from the quadrats sampled at short intervals. Mussels were pooled across quadrats and plots within a combination of habitat and stratum. In the first har. the black shading indicates settlers $(<0.5 \mathrm{~mm}$ SL), while the gray shading indicates individuals which were $0.5-0.9 \mathrm{~mm}$. Brackets show results of Kolmogorov-Smirnov tests comparing the size distributions of mussels between strata within each habitat and between habitats within each stratum $\left(D_{\max } \mathrm{p} ;{ }^{n s} \mathrm{p}>0.5, \cdot \mathrm{p}<0.05\right.$, $\cdots p<0.01, \cdots p<0.001)$
Fig. 4. Mytilus spp. Mean ( $+\mathrm{SE}$ ) density of mussel colonists in ice-scoured and non-scoured tidepools and emergent rock after the 5,11 , and 16 mo intervals beginning in July 1993, and after the second and third 5 to 6 mo intervals. Data were averaged across 3 quadrats per plot and across 3 plots within each combination of habitat and stratum

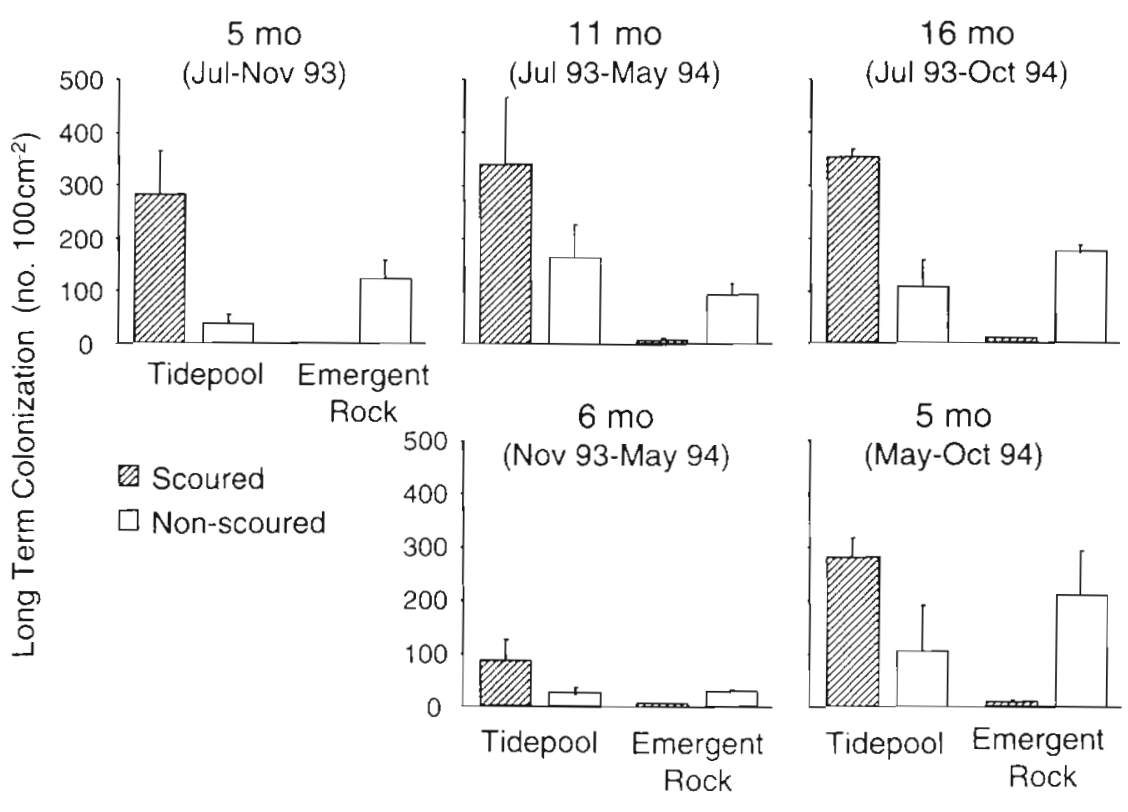


$95 \%$, respectively, of the abundance after 16 mo (159 mussels per $100 \mathrm{~cm}^{2}$, averaged across all habitat/stratum combinations). There were no significant interactions between time interval and either habitat or stratum, nor was there a significant 3-way interaction. The density of colonists also varied significantly among plots within combinations of Habitat and Stratum. For each of the three 5 to 6 mo intervals, ANOVA showed a significant interaction in the effects of habitat and stratum on the density of mussel colonists (Table 4). Differences between habitats within strata, and between strata within habitats, were the same as for the 5, 11, and 16 mo intervals beginning in 1993, except for the third 5 to 6 mo interval when the difference between non-scoured and ice-scoured areas on emergent rock was marginally non-significant

Table 3. Mytilus spp. ANOVA of the number of mussel colonists in $100 \mathrm{~cm}^{2}$ quadrats after the 5,11 , and 16 mo intervals beginning in July 1993. Factors are Habitat (H, tidepools and emergent rock), Stratum ( $\mathrm{S}$, ice-scoured and non-scoured), Plot (nested within $\mathrm{H} \times \mathrm{S})$, and Time $(5,11$, and $16 \mathrm{mo})$. Effects of Habitat, Stratum, and the interaction between Habitat and Stratum were tested against the mean square error of Plot, and effects of Time and the unteractions between Time, Habitat, and Stratum were tested against the mean square error of the interaction between Time and Plot. The effect of Plot and the interaction between Time and Plot were tested against the residual mean square error. $" \mathrm{p}<0.05 ; \cdots p<0.01 ; \cdots p<0.001$. The results of a posteriori tests are presented in the 'Comparison' column. Since there was a significant $H \times S$ interaction, means were compared between habitats within each stratum and between strata within each habitat using $t$-tests (TP = tidepool, ER $=$ emergent rock, $N$-S $=$ nonscoured, $S=i c e-s c o u r e d)$. Since there was a significant effect of Time, means were compared among time intervals $(5=5$ mo,

$11=11 \mathrm{mo}, 16=16 \mathrm{mo})$ using SNK. = indicates a non-significant result, while $<$ or $>$ indicates a significant result $(\alpha=0.05\}$

\begin{tabular}{|c|c|c|c|c|c|}
\hline Source & $\mathrm{df}$ & MS & $F$ & $\mathrm{p}$ & Comparison \\
\hline Habitat & 1 & 25.6 & 23.54 & $0.001^{\cdots}$ & TP: $N-S=S$ \\
\hline Stratum & 1 & 1.94 & 1.78 & 0.22 & ER: $N-S>S$ \\
\hline Habitat $\times$ Stratum & 1 & 25.8 & 23.73 & $0.001^{\cdots}$ & N-S: TP=ER \\
\hline Plot $(\mathrm{H} \times \mathrm{S})$ & 8 & 1.09 & 4.64 & $<0.001 \cdots$ & $\mathrm{S}: \mathrm{TP}>\mathrm{ER}$ \\
\hline Time & 2 & 1.66 & 7.90 & $0.004^{\cdots}$ & $5<11=16$ \\
\hline Habitat $\times$ Time & 2 & 0.48 & 2.28 & 0.13 & \\
\hline Stratum $\times$ Time & 2 & 0.43 & 2.04 & 0.16 & \\
\hline Habitat $\times$ Stratum $\times$ Time & 2 & 0.34 & 1.61 & 0.57 & \\
\hline Time $\times$ Plot $(\mathrm{H} \times \mathrm{S})$ & 16 & 0.24 & 0.90 & 0.23 & \\
\hline Residual & 72 & 0.21 & & & \\
\hline
\end{tabular}

Table 4. Mytilus spp. ANOVA of the number of mussel colonists in $100 \mathrm{~cm}^{2}$ quadrats after the three 5 to 6 mo intervals. Factors are Habitat ( $\mathrm{H}$, tidepools and emergent rock), Stratum ( $\mathrm{S}$, ice-scoured and non-scoured), and Plot (nested within $\mathrm{H} \times \mathrm{S}$ ). Effects of Habitat, Stratum, and the interaction between Habitat and Stratum were tested against the mean square error of Plot, and the effect of Plot was tested against the residual mean square error $p<0.05, \cdots p<0.01 ; \cdots p<0.001$ The results of a posteriori tests are presented in the 'Comparison' column. When there was a significant $\mathrm{H} \times \mathrm{S}$ interaction, means were compared between habitats within each stratum and between strata within each habitat using $t$-tests (TP $=$ tidepool, ER $=$ emergent rock, $N$-S $=$ non-scoured, $S=$ ice-scoured). = indicates a non-significant result, while $<$ or $>$ indicates a significant result $(\alpha=0.05)$

\begin{tabular}{|c|c|c|c|c|c|c|}
\hline Interval & Source & df & MS & $F$ & $\mathrm{p}$ & Comparison \\
\hline \multirow[t]{5}{*}{1 st 5 to $6 \mathrm{mo}$} & Habitat & 1 & 0.46 & 17.82 & $0.003^{\cdots}$ & $T P: N-S=S$ \\
\hline & Stratum & 1 & 8.25 & 0.55 & 0.48 & ER: N-S>S \\
\hline & Habitat $\times$ Stratum & 1 & 0.26 & 27.93 & $<0.001^{\cdots}$ & $N-S: T P=E R$ \\
\hline & Plot $(\mathrm{H} \times \mathrm{S})$ & 8 & 12.93 & 1.51 & 0.21 & $\mathrm{~S}: \mathrm{TP}>\mathrm{ER}$ \\
\hline & Residual & 24 & 0.31 & & & \\
\hline \multirow[t]{5}{*}{$2 \mathrm{nd} 5$ to $6 \mathrm{mo}$} & Habitat & 1 & 3.81 & 10.51 & $0.01^{\circ}$ & TP: $\mathrm{N}-\mathrm{S}=\mathrm{S}$ \\
\hline & Stratum & 1 & 0.13 & 0.37 & 0.56 & ER: N-S>S \\
\hline & Habitat $\times$ Stratum & 1 & 4.13 & 11.4 & $0.01^{\circ}$ & N-S: TP=ER \\
\hline & Plot $(\mathrm{H} \times \mathrm{S})$ & 8 & 0.36 & 2.09 & 0.08 & $S: T P>E R$ \\
\hline & Residual & 24 & 0.17 & & & \\
\hline \multirow[t]{4}{*}{ 3rd 5 to 6 mo } & Habitat & 1 & 1.46 & 1.27 & 0.29 & $T P: N-S=S$ \\
\hline & Stratum & 1 & 0.01 & 0.01 & 0.95 & $E R: N-S=S$ \\
\hline & Habitat $\times$ Stratum & 1 & 11.02 & 9.53 & $0.02^{\circ}$ & N-S: TP=ER \\
\hline & Plot $(\mathrm{H} \times \mathrm{S})$ & 8 & 1.16 & 8.95 & $<0.001 \cdots$ & $S: T P>E R$ \\
\hline
\end{tabular}




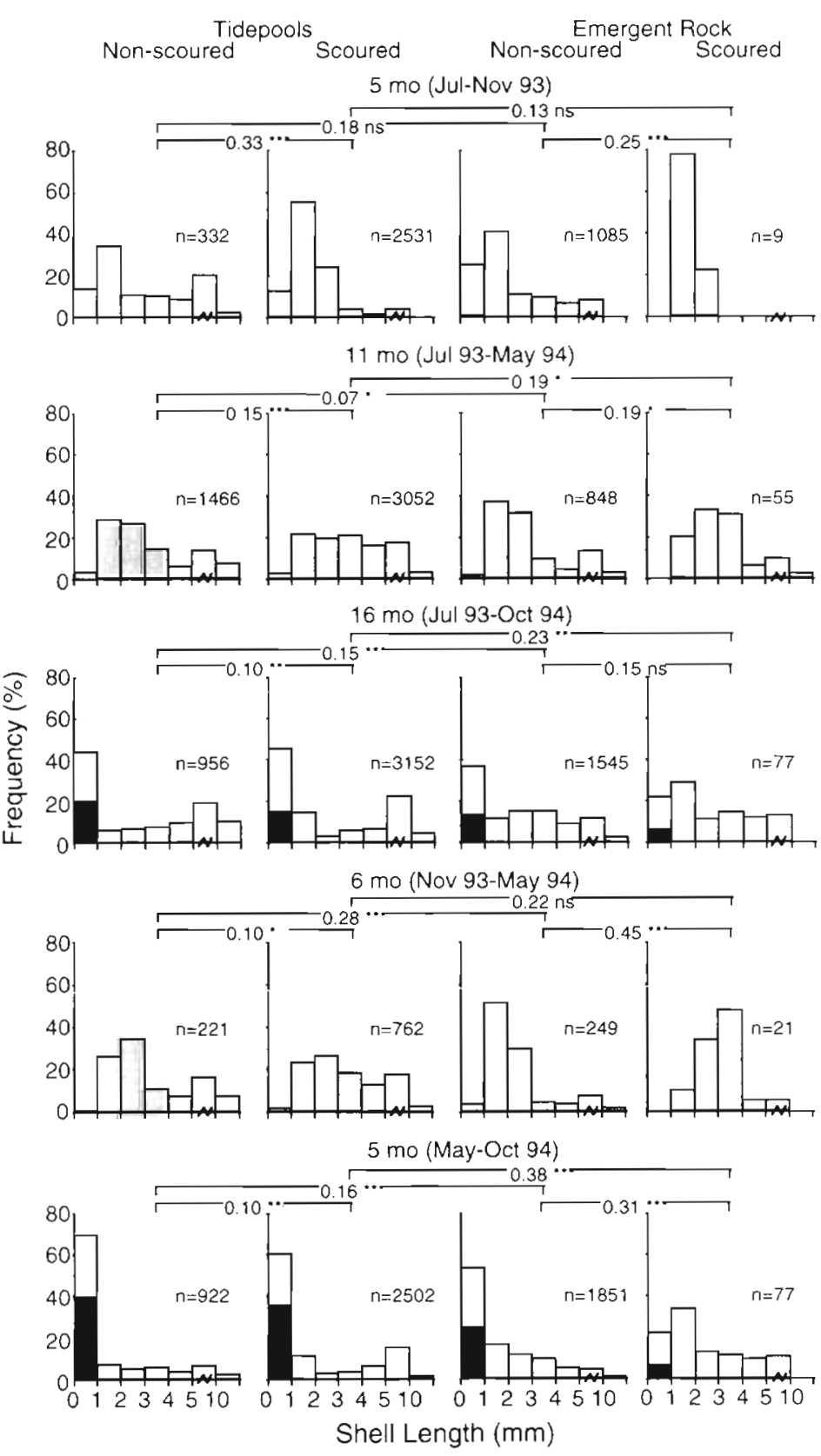

Fig. 5. Mytilus spp. Size frequency distributions of mussels after the 5, 11 , and 16 mo intervals beginning in July 1993, and the second and third 5 to 6 mo intervals. Mussels were pooled across quadrats and plots within a combination of habitat and stratum. In the first bar, the black shading indicates settlers $(<0.5 \mathrm{~mm} \mathrm{SL})$, while the gray shading indicates individuals which were $0.5-0.9 \mathrm{~mm}$. Brackets show results of Kolmogorov-Smirnov tests comparing the size distributions of mussels between strata within each habitat and between habitats within each stratum $\left(D_{\max }, \mathrm{p}_{i}{ }^{n s} \mathrm{p}>0.5, \cdot \mathrm{p}<0.05, \cdots p<0.01, \cdots p<0.001\right)$

(Table 4). Colonization varied significantly among plots within combinations of habitat and stratum after the third, but not the first or second, 5 to 6 mo interval.
After each of the longer term (5 to $16 \mathrm{mo}$ ) intervals, mussels $<5 \mathrm{~mm}$ represented 72 to $100 \%$ of colonists and mussels $>10 \mathrm{~mm}$ represented $<10 \%$ (Fig. 5). We compared the size distributions of colonists between habitats within strata and between strata within habitats for each interval. Differences in the size distributions between combinations of habitat and stratum were not consistent over time and did not reflect the pattern observed in the size distributions of cumulative short term colonization (Figs. 3 \& 5). However, after each of the 5 to 6 mo intervals, and the 11 and 16 mo intervals, mussels $<1 \mathrm{~mm}$ SL were proportionately less abundant on ice-scoured emergent rock than in the other combinations of habitat and stratum. The absence of significant differences in size distributions in some of the comparisons with ice-scoured emergent rock resulted from the smaller sample sizes from this habitat/stratum combination and not from smaller differences between cumulative size frequency distributions. We did not statistically compare the size distributions among time intervals because the differences were clear and larger than the differences between habitats and strata within an interval, and the analyses would have necessitated a large number of comparisons. Mussels $<1 \mathrm{~mm}$ were proportionately least abundant in May 1994, the end of the second 5 to 6 mo interval and the 11 mo interval, and proportionately most abundant in October 1994, at the end of the third 5 to 6 mo interval and the $16 \mathrm{mo}$ interval. Mussels $<0.5 \mathrm{~mm}$ were abundant only in October 1994.

\section{Comparison of sampling frequencies}

To explore the importance of post-colonization mortality and dispersal in determining the abundance of colonists at the end of the 5 to 16 mo intervals, we used regression analysis to examine the relationship between long term (5 to $16 \mathrm{mo}$ ) colonization and cumulative short term ( 2 to 7 d) colonization during each of these intervals (Fig. 6). Long term colonization was significantly related to cumulative short term colonization during the 5,11 and 16 mo intervals beginning in July 1993. The slope of the relationship approached the maximum value of 1 during the first 5 to 6 mo interval and the 11 mo interval, but was lower during the 16 mo interval. During the second 5 to 6 mo interval, long 


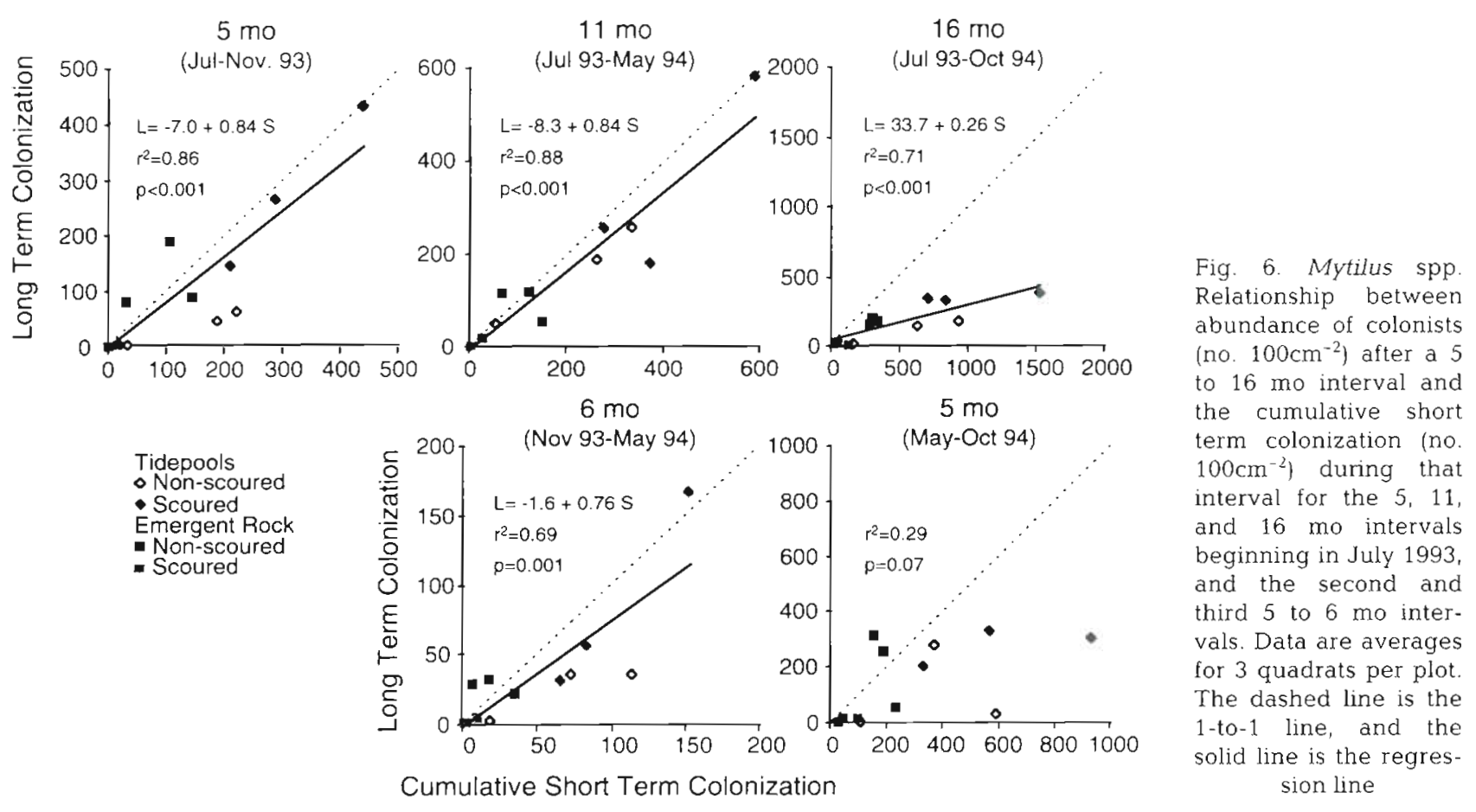

term colonization also was significantly related to cumulative short term colonization, and the slope of the relationship approached 1. However, during the third 5 to 6 mo interval which corresponded to the end of the 16 mo interval, the relationship was marginally non-significant. Results of these analyses should be interpreted cautiously. Because long term colonization is generally constrained to be less than cumulative short term colonization, long and short term colonization will probably be correlated (McGuiness \& Davis 1989). However, the statistically significant relationships explained $>69 \%$ of the variation, which is unlikely to be due to chance.

Differences in the size distributions of colonists sampled at short and long sampling intervals can result from growth of individuals or size specific mortality or dispersal after initial colonization. We compared the size distributions of long term colonists to those of cumulative short term colonists for the first and third 5 to 6 mo intervals (Figs. 3 \& 5) using KolmogorovSmirnov tests. In the first 5 to 6 mo interval, mussels $<1 \mathrm{~mm}$ were proportionately more abundant when colonists were collected at short than at long sampling intervals in both non-scoured $\left(D_{\max }=0.17, \mathrm{p}<0.001\right)$ and ice-scoured tidepools $\left(D_{\max }=0.33, \mathrm{p}<0.001\right)$, but proportionately less abundant when colonists were sampled at short than at long intervals on non-scoured emergent rock $\left(D_{\max }=0.15, \mathrm{p}<0.001\right)$ On ice-scoured emergent rock, where sample sizes were low, size distributions did not differ significantly between sampling frequencies $\left(D_{\max }=0.25, \mathrm{p}>0.10\right)$. In each habitat/stratum combination during the third 5 to 6 mo interval, mussels $<1 \mathrm{~mm}$ were not only proportionately less abundant (tidepools: ice-scoured $D_{\max }=0.46$, nonscoured $D_{\max }=0.65$; emergent rock: ice-scoured $D_{\max }=0.37$, non-scoured $D_{\max }=0.50 ; \mathrm{p}<0.001$ ) but also absolutely less abundant when colonists were sampled at short than at long intervals. These results indicate that, in comparison to the quadrats sampled at short intervals, the abundance of small mussels $(<1 \mathrm{~mm})$ in the long term colonization quadrats was enhanced during the first 5 to 6 mo interval on nonscoured emergent rock and during the third 5 to 6 mo interval in all combinations of habitat and stratum.

\section{Spatial and temporal variation in the macrobenthic assemblage}

The macrobenthic assemblage in the short and long term colonization quadrats varied markedly between habitats and strata (Fig. 7). Jointed calcareous algae were found only in tidepools. Sheet algae were abundant in tidepools in April 1994, but rare on emergent rock (see also Metaxas et al. 1994). Conversely, thick leathery macroalgae and barnacles generally were rare in tidepools, but were more abundant on emergent rock. Ice-scoured emergent rock lacked filamentous algae (except in April 1994) and coarsely branched macroalgae, and had a lower cover of crus- 


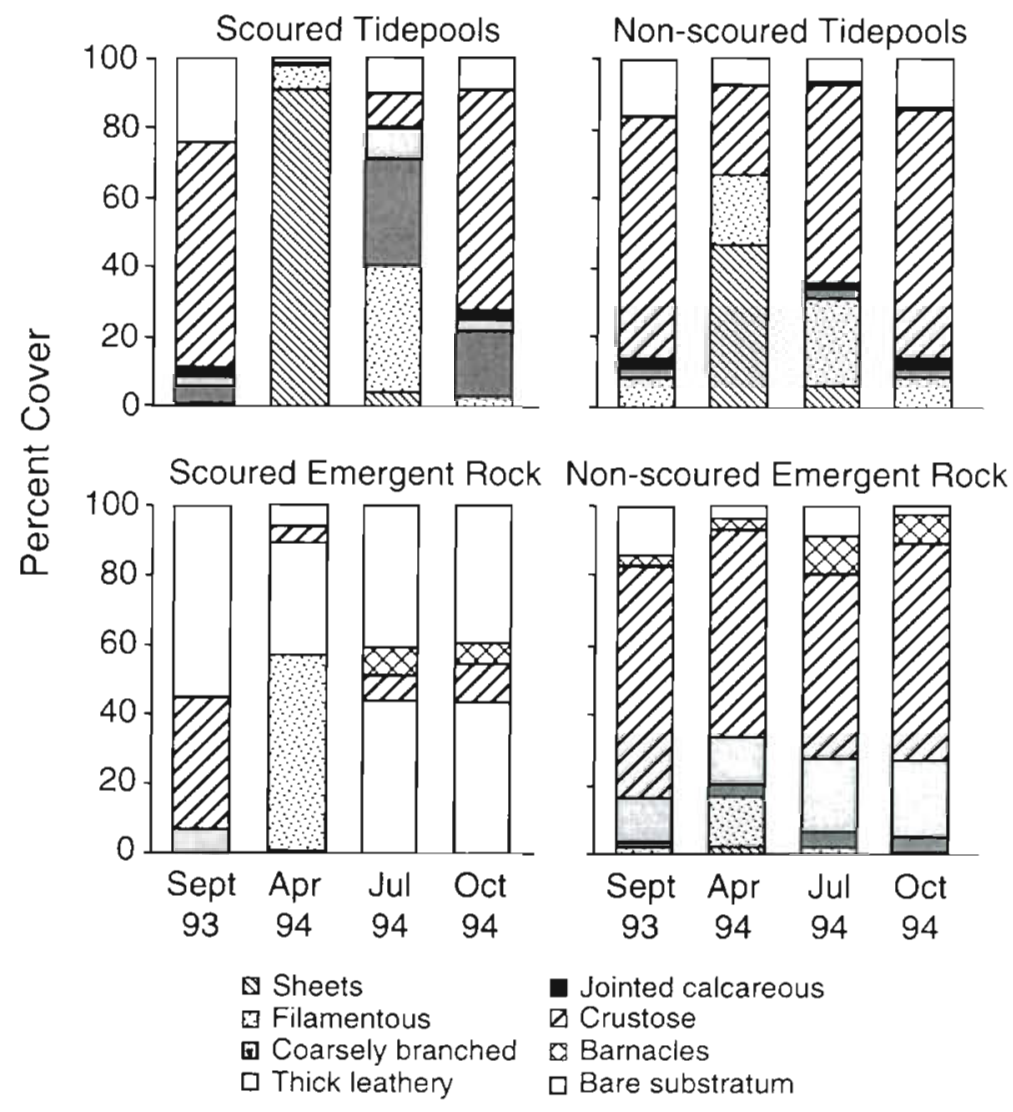

Fig 7 Percentage cover of 6 functional form groups of macroalgae and of barnacles and unoccupied substratum in ice-scoured and non-scoured tidepools and emergent rock in September 1993 and April, August and October 1994. Data were averaged across short and long term colonization quadrats within a plot (12 per plot in September 1993 and April 1994, 9 per plot in August and October 1994) and across 3 plots within each combination of habitat and stratum. Cover of Mytilus spp. in the long term colonization quadrats was not included and percentage cover of macroalgae and barnacles in these quadrats was adjusted to total $100 \%$

tose macroalgae than non-scoured emergent rock and tidepools. In ice-scoured habitats, the macrobenthic assemblage differed between years: there was a greater cover of thick leathery algae and barnacles on ice-scoured emergent rock, and of coarsely branched algae in ice-scoured tidepools, and consequently less unoccupied space in October 1994 than in September 1993.

For the quadrats sampled for long term colonization, we also estimated the cover of mussels. Percentage cover of mussels was less than $1 \%$ after each of the three 5 to 6 mo intervals, with the exception of icescoured tidepools after the third 5 to 6 mo interval $(\bar{x}=$ $6 \%$ ). On average, percentage cover was less than $3 \%$ after 11 mo in each combination of habitat and stratum. After 16 mo, percentage cover of mussels was $<1 \%$ on non-scoured and ice-scoured emergent rock, $8 \%$ in non-scoured tidepools, and $17 \%$ in ice-scoured tide- pools. Because many of the colonists were associated with macroalgae, our low estimates of mussel cover may partly reflect an artifact of our sampling method which recorded only the species/group in the top plane if there were several organisms at the same point on the substratum. How ever, the relatively small size and low abundance $\left(<3 \mathrm{~cm}^{-2}\right)$ of mussel colonists at the end of each of the 5 to 6 mo intervals, the $11 \mathrm{mo}$ interval, and the $16 \mathrm{mo}$ interval indicates that the cover of mussels was probably not greatly underestimated.

\section{DISCUSSION}

\section{Size of colonists and temporal pattern of colonization}

Sampling at short intervals (2 to $7 \mathrm{~d}$ ) indicated that more than $96 \%$ of mussels colonizing the natural substratum were too large (>0.5 $\mathrm{mm}$ ) to be settling larvae. Most of these mussels (67 to $82 \%$ in 1994) were $>2 \mathrm{~mm}$ and some were as large as 20 to $25 \mathrm{~mm}$. Because mussels of this size are probably too heavy to drift in the water column using threads (Sigurdsson et al. 1976, De Blok \& Tan-Maas 1977, Lane et al, 1985), their redistribution occurs either by dislodgment and deposition by waves, or by crawling (Paine 1974, Hunt 1997). In a tagging study, Hunt (1997) found that mussels larger than $5 \mathrm{~mm}$ SL usually moved $<5 \mathrm{~cm}$ over $4 \mathrm{wk}$. Because we cleared a $10 \mathrm{~cm}$ border around our sampling quadrats, it is unlikely that postlarval colonists entered the quadrats by crawling. The size range of colonizing mussels encompassed most of the size range of the mussel population at Cranberry Cove: $\sim 90 \%$ of mussels are smaller than $5 \mathrm{~mm}$ and $<5 \%$ are larger than $20 \mathrm{~mm}$ (Hunt \& Scheibling 1995, in press). Since growth rates are low $\left(\leq 0.4 \mathrm{~mm} \mathrm{mo}^{-1}\right.$ for mussels $>5 \mathrm{~mm}$; Hunt 1997), the large size of many of the colonists indicates that they were several years old. The distance of wave dispersal of large mussels is unknown. However, even relatively small-scale dispersal should increase the rate of recovery of mussel cover from small-scale disturbances and affect the dynamics of established mussel aggregations. At the same field site, Hunt (1997) found that changes in mussel patch size were affected more by dislodgment and redistribution of mussels by waves than by mussel mortality. 
Sampling at short intervals indicated that the colonization rate of mussels $>2 \mathrm{~mm}$ SL peaked in June to July in both 1993 and 1994. In contrast, settlement occurred in August to October, similar to the pattern observed by Pedersen (1991) at another wave-exposed shore $-30 \mathrm{~km}$ from our site. The peak of colonization of large mussels in late spring and summer may be associated with the low wave action at this time of year. In June and July of both years, $<9 \%$ of measurements of significant wave heights recorded at the mouth of $\mathrm{Hal}$ ifax Harbour $\left(44.483^{\circ} \mathrm{N}, 63.417^{\circ} \mathrm{W}, \sim 40 \mathrm{~km}\right.$ from our study site) were $>2 \mathrm{~m}$ (unpubl. data, Department of Fisheries and Oceans, Ottawa, Canada). In contrast, from September 1993 to May 1994, 11 to $45 \%$ of records in each month were $>2 \mathrm{~m}$. Decreased wave action is associated with decreased attachment strength of mussels to the substratum (Price 1980, 1982, Witman \& Suchanek 1984, Hunt 1997). Consequently, during periods of low wave heights, the probability of a mussel's dislodgment by occasional large waves may have been increased.

The influence of colonization by mussels $>2 \mathrm{~mm}$ is not usually considered in studies of the dynamics of mussel assemblages on hard substrata, although dispersal by smaller post-larval mussels is well known. Detection of the movement of large mussels may depend on the substratum used to monitor colonization. Most studies of patterns of settlement or recruitment of mussels have monitored artificial substrata (usually filamentous) and have found no evidence of colonization by mussels $>5 \mathrm{~mm}$ (e.g. De Blok \& Geelen 1958, King et al. 1990, Cáceres-Martínez et al. 1994). In contrast, Paine (1974) observed that large Mytilus californianus $(>3 \mathrm{~cm}$ ) colonized plots of the natural substratum which had been cleared of mussels. We found that mussels that colonized natural substrata were larger than those which colonized an artificial filamentous substratum, suggesting that filamentous substrata are more suitable for smaller than for larger mussels (Hunt \& Scheibling 1996). The high rates of colonization by large mussels in our study compared to others also may result from differences between mussel species. Genetic analysis indicated that $\sim 70 \%$ of mussels at our study site were $M$. trossulus, while most of the studies employing artificial substrata examined M. edulis or M. galloprovincialis.

\section{Patterns of colonization among habitats and strata}

Colonization by Mytilus, measured both at short ( 2 to 7 d) and long (5 to $16 \mathrm{mo}$ ) sampling intervals, differed consistently among combinations of habitat and stratum. Mussel colonization was greatest in ice-scoured tidepools and lowest on ice-scoured emergent rock.
Although spatial distribution is known to vary among some of the closely related species in the $M$. edulis species complex (e.g. $M$. edulis and $M$. galloprovincialis; Skibinski et al. 1983, Gosling \& McGrath 1990), variation in the distribution of $M$. trossulus and $M$. edulis probably did not contribute to the pattern we observed, since genetic analysis indicated that the frequency of occurrence of the 2 species did not differ between tidepools and emergent rock.

Variation in colonization rates among combinations of habitat and stratum was probably influenced by variation in the macrobenthic assemblage. We observed mussel colonists on a variety of substrata, including filamentous algae (Cladophora sp., Spongomorpha sp.), jointed calcareous alga (Corallina officinalis), holdfasts of thick leathery macroalgae (Fucus vesiculosis, Chondrus crispus), pits and crevices in rock covered by crustose algae (Phymatolithon sp., Hildenbrandia rubra), and barnacle tests. In contrast, we rarely observed mussel colonists on smooth, otherwise unoccupied substrata. During the 17 mo period of this study, the macrobenthic assemblage differed among the habitat/stratum combinations, and the percentage cover of different macroalgal groups and barnacles varied over time. Ice-scoured emergent rock, the habitat/stratum combination with the lowest abundance of colonists, generally lacked filamentous and coarsely branched algae, substrata with which recently settled mussels are often associated (authors' pers. obs., see also Seed \& Suchanek 1992, Hunt \& Scheibling 1996). Filamentous algae was abundant on icescoured emergent rock only in April 1994 when the short term colonization rate of mussels was negligible. Ice-scoured emergent rock also had less crustose macroalgae than the other habitat/stratum combinations. In a previous paper, we investigated the factors influencing the pattern of mussel colonization among the habitat/stratum combinations by comparing colonization rates on natural and artificial substrata (Hunt \& Scheibling 1996). In contrast to the natural substratum, colonization of artificial substrata was greatest on ice-scoured emergent rock in direct relation to water flux (Hunt \& Scheibling 1996). The difference in colonization pattern between artificial and natural substrata indicated that colonization of natural substrata is influenced by factors other than water flux, including variation in the macrobenthic assemblage between habitats and strata (Hunt \& Scheibling 1996).

Within combinations of habitat and stratum, the cumulative short term and long term abundance of colonists often varied among plots. Spatial variation in colonization at the scale of plots may result from variation in the supply of colonists due to differences in tidal height and wave exposure, or from variation in the macrobenthic assemblage. We also observed consider- 
able variability in the abundance of colonists among quadrats within plots, most likely resulting from variation in the macrobenthic assemblage.

The patterns of colonization on natural substrata correspond to patterns of distribution and abundance of mussels on ice-scoured but not on non-scoured regions of the shore. Colonization rate of ice-scoured emergent rock was low during all sampling intervals and mussels are rare in these areas. In non-scoured areas, the spatial distribution and abundance of mussels differ between tidepools and emergent rock, but we did not detect a difference in colonization rate between the 2 habitats. However, the small size and low percentage cover of mussels after 16 mo $(\leq 17 \%)$ suggests that differences in the mussel assemblage between the tidepools and emergent rock develop slowly. This is consistent with studies of community recovery on waveexposed shores on the Atlantic coast of Nova Scotia after a large scale ice scour in 1987 (McCook \& Chapman 1997, Minchinton et al. 1997). On emergent rock in the mid intertidal zone, mussel cover was $<20 \% 14$ mo after the ice scour (McCook \& Chapman 1997, Minchinton et al. 1997). The pattern of distribution and cover of mussels did not resemble the pre-disturbance pattern until 5 yr after the ice scour (Minchinton et al. 1997).

\section{Sampling frequency}

Patterns of mussel colonization among habitats and strata were similar regardless of the length of the sampling interval. This indicates that, over time scales up to $16 \mathrm{mo}$, patterns of initial colonization were more important than post-colonization processes in determining the pattern of spatial distribution of mussels. In addition, the long term abundance of colonists was linearly related to the cumulative short term abundance during each interval except the third 5 to 6 mo interval. With the exception of the 16 mo interval, there was approximately a 1-to-1 relationship between long term and cumulative short term colonization, implying that little post-colonization mortality or dispersal occurred during these intervals. The low percentage cover of mussels after each of the intervals indicates that there was probably little or no competition for space. However, some post-colonization mortality or dispersal may have been offset by enhanced settlement in the presence of conspecifics in the long term colonization quadrats. As evidence of this, the abundance of $<1 \mathrm{~mm}$ mussels after the third 5 to 6 mo interval, immediately after a settlement peak in 1994, was greater than the cumulative abundance based on short term sampling over the same interval. This disparity was not observed after the first 5 to 6 mo interval in 1993 when quadrats were sampled a month after the settlement peak. This increase in the estimate of settlement in quadrats from which individuals have not been cleared is contrary to the observations for barnacles (Connell 1985, Bertness et al. 1992, Minchinton \& Scheibling 1993a, b). However, barnacles require free space on the substratum for settlement, wheareas mussels generally settle on filamentous or rough substrata, which can include the byssal threads of conspecifics. For example, Hunt (1997) found a positive relationship between recruitment rate of mussels to mussel patches and patch area.

The lack of a significant relationship between long term and cumulative short term colonization for the third 5 to 6 mo interval suggests that density-dependent post-colonization processes were more important during this interval, when cumulative short term colonization was highest, than during the other 5 to 16 mo intervals. Post-colonization processes also influenced the size distributions of colonists. On ice-scoured emergent rock (except in fall 1994), the size range of long term colonists was more limited than that of colonists sampled at short intervals. This suggests that ice-scoured emergent rock is not a suitable substratum for some sizes of mussels, particularly those $<1 \mathrm{~mm}$, and that many mussels died or emigrated after initial colonization. Small mussels were relatively more abundant in ice-scoured tidepools than in the other combinations of habitat and stratum at short sampling intervals, but this pattern was not as apparent at long sampling intervals. This change could result from differences among habitat and stratum combinations in the rates of mortality, dispersal, or growth of small mussels. Hunt (1997) found that growth rates of large mussels (>5 mm) were slightly higher in tidepools than on emergent rock over 5 mo intervals. The size distributions of long term colonists also may be influenced by an increased attractiveness of the substratum to settling larvae due to the presence of conspecifics, as discussed above.

Our study demonstrates the potential importance of post-settlement dispersal in determining the distribution and population dynamics of benthic marine invertebrates which remain mabile for a period of time after settlement. We found that dispersing post-larval mussels were considerably more abundant than settlers and that mussels $>2 \mathrm{~mm}$ represented a large proportion of colonists. Colonization by mussels $>2 \mathrm{~mm}$ may be overlooked in many studies of mussel colonization. because most researchers use a filamentous artificial substratum, which may be more suitable for smaller than for larger post-larval mussels. Our results indicate that, over time scales up to $16 \mathrm{mo}$, patterns of initial colonization by settlers and larger post-larval mussels were more important than post-colonization mortality and dispersal in determining patterns of distribution and abundance of mussels on this shore. 
Acknowledgements. We thank Norman Countway, Allan Hennigar, Anna Metaxas, Kristina Sander, and Alyson Shaw for assistance in the field. We are also grateful to Sharlene Anthony for counting samples and to Dr S. Walde for comments on an earlier draft of this manuscript. H.L.H. was supported by a Natural Science and Engineering Research Council (NSERC) Postgraduate Award and an Izaak Walton Killam Memorial Scholarship from Dalhousie University, and the research was supported by an NSERC Research Grant to R.E.S.

\section{LITERATURE CITED}

Armonies W (1992) Migratory rhythms of drifting juvenile molluscs in tidal waters of the Wadden Sea. Mar Ecol Prog Ser 83:197-206

Bayne BL (1964) Primary and secondary settlement in Mytilus edulis L. (Mollusca). J Anim Ecol 33:513-523

Bayne BL (1965) Growth and the delay of metamorphosis of the larvae of Mytilus edulis (L.). Ophelia 2:1-47

Bertness MD, Gaines SD, Stephens EG, Yund PO (1992) Components of recruitment in populations of the acorn barnacle Semibalanus balanoides (Linnaeus). J Exp Mar Biol Ecol 156:199-215

Beukema JJ, de Vlas J (1989) Tidal-current transport of thread-drifting postlarval juveniles of the bivalve Macoma balthica from the Wadden Sea to the North Sea. Mar Ecol Prog Ser 52:193-200

Butman CA (1987) Larval settlement of soft sediment invertebrates: the spatial scales of pattern explained by active habitat selection and the emerging role of hydrodynamical processes. Oceanogr Mar Biol Annu Rev 25:113-165

Cáceres-Martínez J, Robledo JAF, Figueras A (1993) Settlement of mussels Mytilus galloprovincialis on an exposed rocky shore in Ria de Vigo, NW Spain. Mar Ecol Prog Ser 93:195-198

Cáceres-Martínez J, Robledo JAF, Figueras A (1994) Settlement and post-larvae behaviour of Mytilus galloprovincialis: field and laboratory experments. Mar Ecol Prog Ser 112:107-117

Connell JH (1985) The consequences of variation in initial settlement vs. post-settlement mortality in rocky intertid.al communities. J Exp Mar Biol Ecol 93:11-45

De Blok JW, Geelen HJFM (1958) The substratum required for the settling of mussels (Mytilus edulis L.). Arch Neerl Zool 13:446-460

De Blok JW, Tan-Maas M (1977) Function of byssus threads in young postlarval Mytilus. Nature 267:558

Gosling EM. McGrath D (1990) Genetic variability in exposed-shore mussels, Mytilus spp., along an environmental gradient. Mar Biol 104:413-418

Heath DD, Rawson PD, Hilbish T (1995) PCR-based nuclear markers identify alien blue mussel (Mytilus spp.) genotypes on the west coast of Canada. Can J Fish Aquat Sci $52: 2621-2627$

Hunt HL (1997) Structure and dynamics of intertidal mussel (Mytilus trossulus, $M$. edulis) assemblages. PhD thesis, Dalhousie University, Halifax

Hunt HL. Scheibling RE (1995) Structure and dynamics of mussel patches in tidepools on a rocky shore in Nova Scotia, Canada. Mar Ecol Prog Ser 124:105-115

Hunt HL, Scheibling RE (1996) Physical and biological factors influencing mussel (Mytilus trossulus, $M$. edulis) settlement on a wave-exposed rocky shore. Mar Ecol Prog Ser 142:135-145

Hunt HL, Scheibling RE (in press) Effects of whelk (Nucella lapillus (L.) predation on mussel (Mytilus trossulus (Gould), $M$. edulis (L.)) assemblages in tidepools and on emergent rock on a wave-exposed rocky shore in Nova Scotia, Canada. J Exp Mar Biol Ecol

King PA, McGrath D, Britton W (1990) The use of artificial substrates in monitoring mussel (Mytilus edulis L.) settlement on an exposed rocky shore in the west of Ireland. $\mathrm{J}$ Mar Biol Assoc UK 70:371-380

King PA, McGrath D, Gosling EM (1989) Reproduction and settlement of Mytilus edulis on an exposed shore in Galway Bay, west coast of Treland. J Mar Biol Assoc UK 69: $355-365$

Lane DJW, Beaumont AR, Hunter JR (1985) Byssus drifting and the drifting threads of the young post-larval mussel Mytilus edulis. Mar Biol 84:301-308

Littler MM (1980) Morphological form and photosynthetic performances of marine macroalgae: tests of a functional/form hypothesis. Bot Mar 22:161-1.65

Littler MM, Littler DS (1984) Relationships between macroalgal functional form groups and substrata stability in a subtropical rocky-intertidal system. J Exp Mar Biol Ecol 74: $13-34$

Martel A. Chia FS (1991a) Foot-raising behaviour and active participation during the initial phase of post-metamorphic drifting in the gastropod Lacuna spp. Mar Ecol Prog Ser $72: 247-254$

Martel A. Chia FS (1991b) Drifting and dispersal of small bivalves and gastropods with direct development. J Exp Mar Biol Ecol 150:131-1.47

McCook LJ, Chapman ARO (1997) Patterns and variations in natural succession following massive ice-scour of a rocky intertidal seashore. J Exp Mar Biol Ecol 214:121-147

McGrath D, King PA, Gosling EM (1988) Evidence for the direct settlement of Mytilus edulis larvae on adult mussel beds. Mar Ecol Prog Ser 47:103-106

McGuiness KA, Davis AR (1989) Analysis and interpretation of the recruit-settler relationship. J Exp Mar Biol Ecol 134 : $197-202$

Metaxas A, Hunt HL, Scheibling RE (1994) Spatial and temporal variability of macrobenthıc communities in tidepools on a rocky shore in Nova Scolia, Canada. Mar Ecol Prog Ser 105:89-103

Minchinton TE, Scheibling RE (1993a) Free space availability and larval substratum selection as determinants of barnacle population structure in a developing rocky intertidal community. Mar Ecol Prog Ser 95:233-244

Minchinton TE, Scheibling RE (1993b) Variations in sampling procedure and frequency affect estimates of recruitment of barnacles. Mar Ecol Prog Ser 99:83-88

Minchinton TE, Scheibling RE, Hunt HL (1997) Recovery of an intertidal assemblage following massive ice scour in Nova Scotia, Canada. Bot Mar 40:139-148

Paine RT (1974) Intertidal community structure: experimental studies on the relationship between a dominant competitor and its principal predator. Oecologia 15:93-120

Pawlik JR (1992) Chemical ecology of the settlement of benthic marine invertebrates. Oceanogr Mar Biol Annu Rev 30:273-335

Pedersen EM (1991) Population genetics of Mytilus from a developing intertidal community in Nova Scotia, Canada. MSc thesis, Dalhousie University, Halifax

Price HA (1980) Seasonal variation in the strength of byssal attachment of the common mussel Mytilus edulis L. J Mar Biol Assoc UK 60: 1035-1037

Price HA (1982) An analysis of factors determining seasonal variation in the byssal attachment strength of Mytilus edulis. J Mar Biol Assoc UK 62:147-155 
Rodriguez SR, Ojeda FP, Inestrosa NC (1993) Settlement of benthic marine invertebrates. Mar Ecol Prog Ser 97: $193-207$

Seed R (1969) The ecology of Mytilus edulis L. (Lamellibranchiata) on exposed rocky shores I. Breeding and settlement. Oecologia 3:277-316

Seed R, Suchanek TH (1992) Population and community ecology of Mytilus. In: Gosling E (ed) The mussel Mytilus: ecology, physiology, genetics, and culture. Elsevier, New York, p 87-169

Sergel S, Castellan NJ Jr (1988) Nonparametric statistıcs for

Editorial responsibility: Roger Hughes (Contributing Editor), Gwynedd, UK the behavioral sciences. McGraw-Hill, New York Sigurdsson JB, Titman CW, Davies PA (1976) The dispersal of young post-larval bivalve molluscs by byssus threads. Nature 262:386-387

Skibinski DOF, Beardmore JA, Cruss TF (1983) Aspects of the population genetics of Mytilus (Mytilidae; Mollusca) in the British Isles. Biol J Linn Soc 19:137-183

Witman JD, Suchanek TH (1984) Mussels in flow: drag and dislodgement by epizoans. Mar Ecol Prog Ser 16:259-268

Woodin SA (1991) Recruitment of infauna: positive or negative cues? Am Zool 31:797-807

Submitted: December 2, 1997; Accepted: March 18, 1998

Proofs received from author(s): May 19, 1998 